\title{
Epidemiology of Helicobacter pylori infection among dyspepsia patients in South-East, Nigeria
}

\author{
${ }^{1}$ Ezugwu, R.I.* and ${ }^{2}$ Chukwubike, C. \\ Department of Applied Microbiology and Brewing, Nnamdi Azikiwe University. P.M.B. 5025, Awka, Nigeria.
}

\begin{abstract}
Helicobacter pylori colonize more than $50 \%$ of the world population and it is considered as one of the major causes of health problem in humans. A total of 643 fresh faecal samples were collected from dyspepsia patients in 11 hospitals within the densely populated area of south-east, Nigeria. The faecal samples were cultured on H. pylori selective medium, Columbia Blood Agar Base with supplement (Oxoid) and incubated at $37^{\circ} \mathrm{C}$ in a microaerophilic environment for 3-7 days following the standard procedures as recommended by the National Committee for Clinical Laboratory Standards (NCCLS). Out of the 643 samples, 487 tested positive to H. pylori. Epidemiological factors such as overcrowding, use of untreated or faecal contaminated water, lack of basic hygiene with regards to the use of toilet, age, gender and level of education must have led to the high prevalence rate of the organism. Adequate hygiene is recommended for the control of the spread of the organism.
\end{abstract}

Keywords: Epidemiology, Helicobacter pylori, Dyspepsia patients

\section{Introduction}

Helicobacter pylori is an important pathogen for gastroduodenal diseases and more than $50 \%$ of the world's population are infected with the bacterium, making it one of the most widespread infection in the world. Actual infection rates vary from nation to nation; the developing world has much higher infection rates than the developed world. Those living in developing countries or crowded, unsanitary conditions are most likely to contract the bacterium, which is passed from person to person via either an oral-oral or faecal-oral route or both (David and George, 2009).

As a result of the childhood-acquired and usually life-long (unless eradicated) infection, about $12-24 \%$ of the H. pylori positive subjects develop severe diseases e.g. peptic ulcers or gastric malignancy. Infection rates are higher in developing countries rather than developed countries as $80-90 \%$ of the population are infected (Fozieh et al., 2014). In developing countries or underdeveloped rural areas, it can be acquired via environmental contamination, leading to higher infection prevalence. Human is the main reservoir of this infection (Fozieh et al., 2014 and Lyudmila, 2011). Infected mother and older siblings are important factors for H. pylori transmission to children. The transmission routes are oral-oral (by saliva), which prevails in the developed world, faecal-oral (person-to-person or by contaminated water, or maybe food), mainly in the developing countries or gastro-oral (by vomiting and regurgitation). Role of viable but not culturable coccoid forms and biofilms appears to be important. Oral H. pylori seems to be associated with combined oral and gastric infections, probably more often in the developing countries. The infection prevalence is still high in countries/groups with poor socio-economic status (Lyudmila, 2011 and Mohammed, et al., 2010).

\section{Sample collection}

\section{Materials And Method}

A total of 643 fresh faecal samples were collected from dyspepsia patients in eleven (11) hospitals located within the densely populated area of the five (5) states that make up the South-east zone of Nigeria. The samples were collected using sterile wide mouth universal containers and were analysed within $1 \mathrm{hr}$ after collection. The sample collection was complemented by the use of questionnaires and oral interview of the patients to obtain information relevant to the study.

\section{Preparation of Columbia Blood Agar Base.}

Thirty nine grams of Columbia Blood Agar Base (Oxoid) was weighed and dissolved in 1000mls of distilled water. It was dispensed in $500 \mathrm{mls}$ conical flask and was boiled to dissolve completely before it was sterilized by autoclaving at $121^{\circ} \mathrm{C}$ for 15 mins. It was allowed to cool to $50^{\circ} \mathrm{C}$ before the $\mathrm{H}$. pylori supplement was added.

\section{Preparation of H. pylori Selective Supplement.}

The supplement was prepared by dissolving 1 (one) supplement vial (Oxoid) with $1 \mathrm{ml}$ of ethanol and $1 \mathrm{ml}$ of sterile distilled water. The whole content was aseptically added into $500 \mathrm{mls}$ of already sterilized 
Columbia Blood Agar Base which has cooled to $50^{\circ} \mathrm{C}$. Twenty five (25) $\mathrm{mls}$ of defibrinated sheep blood was added and the whole content was properly mixed before pouring into sterile Petri dishes.

\section{Isolation}

Two grams of the various fresh faecal samples were weighed and immersed into various test tubes containing $10 \mathrm{mls}$ of phosphate buffered saline (PBS). The test tubes were then vortexed. One loopful of the content from the various test tubes was aseptically inoculated on the Columbia Blood Agar Base with supplement (Oxoid). The inoculated plates were transferred into candle jar and incubated under microaerophilic environment at $25^{\circ} \mathrm{C}, 37^{\circ} \mathrm{C}$ and $42^{\circ} \mathrm{C}$ for $3-7$ days. The candle jar was disinfected using $70 \%$ alcohol and a humid atmosphere was maintained in the jar by placing moist filter paper or moist cotton wool at the bottom of the jar. ( Kohanteb et al., 2007).

\section{Identification of Helicobacter pylori.}

Colonies with typically small, round, translucent to yellow colour of $0.5-1 \mathrm{~mm}$ in diameter were selected for identification (Raul et al., 2004).

The following biochemical tests were carried out as described by (Cheesebrough, 2004) to confirm that the suspected colonies were Helicobacter pylori. They include: urease, oxidase, catalase, nitrate reduction and indoxyl acetate hydrolysis test.

\section{Statistical Analysis}

The relationship between the occurrence of the organism and the epidemiological factors were analysed using SPSS version 17.0 (SPSS Inc. Chicago Illinois). Please note that all the tests were analysed at 5\% level of significant ( $\alpha=0.05$ ). A P value less than 0.05 was accepted as statistically significant.

\section{Results}

Table 1: Result of the biochemical tests used for identifying $H$. pylori

\begin{tabular}{|c|c|}
\hline Biochemical test & Result \\
\hline Catalase test.................... & Positive \\
\hline Oxidase test................... & Positive \\
\hline Urease test.................... & Positive \\
\hline Nitrate reduction test........... & Negative \\
\hline Indoxyl acetate hydrolysis...... & Negative \\
\hline Microaerophilic growth at & \\
\hline $25^{\circ} \mathrm{C} \ldots \ldots \ldots \ldots \ldots \ldots \ldots \ldots \ldots \ldots \ldots \ldots \ldots$ & Negative \\
\hline $37^{\circ} \mathrm{C} \ldots \ldots \ldots \ldots \ldots$ & Positive \\
\hline $42^{\circ} \mathrm{C} \ldots \ldots \ldots \ldots \ldots \ldots \ldots \ldots \ldots \ldots \ldots \ldots \ldots \ldots$ & Negative \\
\hline Gram staining................. & $\begin{array}{l}\text { Gram negative } \\
\text { curved rods }\end{array}$ \\
\hline
\end{tabular}

The study shows that females were more infected than males. The Chi-square value $\mathrm{P}=0.000$, shows that there was a statistical relationship between the occurrence of Helicobacter pylori, and the epidemiological factor (gender) (table 2).

It was also observed that the occurrence of the organism was dependent on the age of the patients. The results show that the organism is usually acquired during childhood (under 10 years), between 11years and above 50 years of age. The Chi-square value of $\mathrm{P}=0.000$ also proved that there was a statistical relationship between the occurrence of the organism and the age of the patients (table 3).

The study shows that the organism was isolated more from those patients living in high density populated areas. The calculated Chi-square value, $\mathrm{P}=0.000$, proved that there was a significant relationship between the organisms' occurrence and the epidemiological factor (overcrowding). This shows that overcrowding has an effect on the occurrence of the organism. Since Helicobacter pylori can be transmitted directly from person to person, over crowding is therefore a great risk factor in the spread of the infection (table 4).

The prevalence of Helicobacter pylori was greatly influenced by the kind of water used by the patients. The organism was isolated more from those patients that used well, stream/river and rain water. This was probably due to faecal contaminants. The water from the well could have been contaminated through the septic tanks or pit toilets located close to the well. The stream/river may also have been contaminated through the sewage from the septic tanks or pit toilets which is usually deposited into nearby stream or river thereby causing contamination. The Chi-square value of $\mathrm{P}=0.002$ proved that the organisms' occurrence was dependent on the type of water used by the patients (table 5).

It was observed that the type of toilet facility used by the patients had an effect on the occurrence of the organism. Three types of toilet facilities were used by the patients as observed during the study: water closet, pit 
and bush method. It was observed that the use of either of the three types of toilet facilities in question had an effect on the occurrence of the organism as confirmed by the Chi-square value, $\mathrm{P}=0.000$ (table 6).

The study also revealed that the organism was isolated more from those patients that had only primary education. This was because they had little or no knowledge of hygiene. Poor hygiene or lack of cleanliness has a great effect on the dissemination of Helicobacter pylori as indicated by the Chi-square result, $\mathrm{P}=0.000$. It proved that there was a direct relationship between the occurrence of the organism and the epidemiological factor (level of education) (table 7).

Table 2: Studying Relationship between Prevalence of Helicobacter pylori and Gender

\begin{tabular}{llcll}
\hline Gender & No sampled & $\begin{array}{l}\text { No of positive } \\
\text { Samples }(\%)\end{array}$ & $\begin{array}{l}\text { No of negative samples } \\
(\%)\end{array}$ & $\begin{array}{l}\text { R/ship with factor @ } \mathrm{p} \leq \\
0.05\end{array}$ \\
\hline Male & 281 & $191(39.22)$ & $90(57.69)$ & 0.000 \\
Female & 362 & $296(60.78)$ & $66(42.31)$ & 0.000 \\
Total & $\mathbf{6 4 3}$ & $\mathbf{4 8 7}(\mathbf{7 5 . 7 3})$ & $\mathbf{1 5 6}(\mathbf{2 4 . 2 6})$ & \\
\hline
\end{tabular}

Table 3: Studying Relationship between Prevalence of Helicobacter pylori and Age

\begin{tabular}{lllll}
\hline Age (Years) & No sampled & $\begin{array}{c}\text { No of positive } \\
\text { samples }(\%)\end{array}$ & $\begin{array}{l}\text { No of negative } \\
\text { samples }(\%)\end{array}$ & $\begin{array}{l}\text { R/ship with factor @ } \\
\text { p } \leq 0.05\end{array}$ \\
\hline Under 10 & 71 & $53(10.88)$ & $18(11.54)$ & 0.000 \\
$11-20$ & 45 & $22(4.52)$ & $23(14.74)$ & 0.000 \\
$21-30$ & 79 & $53(10.88)$ & $26(16.67)$ & 0.000 \\
$31-40$ & 99 & $73(14.99)$ & $26(16.67)$ & 0.000 \\
$41-50$ & 149 & $116(23.82)$ & $33(21.15)$ & 0.000 \\
Above 50 & 200 & $170(34.91)$ & $30(19.23)$ & 0.000 \\
Total & $\mathbf{6 4 3}$ & $\mathbf{4 8 7}(\mathbf{7 5 . 7 3 )}$ & $\mathbf{1 5 6}(\mathbf{2 4 . 2 6})$ & \\
\hline
\end{tabular}

Table 4: Studying Relationship between Prevalence of Helicobacter pylori and Population Size

\begin{tabular}{llccc}
\hline Population & No sampled & $\begin{array}{l}\text { No of positive } \\
\text { samples }(\%)\end{array}$ & $\begin{array}{l}\text { No of negative } \\
\text { samples }(\%)\end{array}$ & $\begin{array}{l}\text { R/ship with factor @ } \\
\mathrm{p} \leq 0.05\end{array}$ \\
\hline High & 288 & $252(51.75)$ & $36(23.08)$ & 0.000 \\
Medium & 203 & $149(30.59)$ & $54(34.62)$ & 0.000 \\
Low & 152 & $86(17.66)$ & $66(42.30)$ & 0.000 \\
Total & $\mathbf{6 4 3}$ & $\mathbf{4 8 7}(\mathbf{7 5 . 7 3})$ & $\mathbf{1 5 6}(\mathbf{2 4 . 2 6})$ & \\
\hline
\end{tabular}

Table 5: Studying Relationship between Prevalence of Helicobacter pylori and Sources of Water

\begin{tabular}{|c|c|c|c|c|c|}
\hline $\begin{array}{l}\text { Source of } \\
\text { supply }\end{array}$ & water & No sampled & $\begin{array}{l}\text { No of positive } \\
\text { samples }(\%)\end{array}$ & $\begin{array}{l}\text { No of negative } \\
\text { samples }(\%)\end{array}$ & $\begin{array}{l}\text { R/ship with factor } \\
\text { (a) } \mathrm{p} \leq 0.05\end{array}$ \\
\hline Tap & & 96 & $60(12.32)$ & $36(23.07)$ & 0.002 \\
\hline Well & & 159 & $124(25.46)$ & $35(22.43)$ & 0.002 \\
\hline Stream / river & & 175 & $147(30.18)$ & $28(17.95)$ & 0.002 \\
\hline Borehole & & 112 & $81(16.63)$ & $31(19.87)$ & 0.002 \\
\hline Rain & & 101 & $75(15.40)$ & $26(16.67)$ & 0.002 \\
\hline Total & & 643 & $487(75.73)$ & $156(24.26)$ & \\
\hline
\end{tabular}

Table 6: Studying Relationship between Prevalence of Helicobacter pylori and Type of Toilet Used

\begin{tabular}{|c|c|c|c|c|}
\hline Type of toilet used & No sampled & $\begin{array}{l}\text { No of positive } \\
\text { samples }(\%)\end{array}$ & $\begin{array}{l}\text { No of negative } \\
\text { Samples (\%) }\end{array}$ & $\begin{array}{l}\mathrm{R} / \text { ship with factor } @ \\
\mathrm{p} \leq 0.05\end{array}$ \\
\hline Water closet & 233 & $191(39.22)$ & $42(26.92)$ & 0.000 \\
\hline Pit & 237 & $159(32.65)$ & $78(50.00)$ & 0.000 \\
\hline Bush & 173 & 137 (28.13) & $36(23.08)$ & 0.000 \\
\hline Total & 643 & 487 (75.73) & $156(24.26)$ & \\
\hline
\end{tabular}

Table 7: Studying Relationship between Prevalence of Helicobacter pylori and Educational Level

\begin{tabular}{llccl}
\hline $\begin{array}{l}\text { Educational } \\
\text { level }\end{array}$ & No sampled & $\begin{array}{c}\text { No of positive } \\
\text { Samples }(\%)\end{array}$ & $\begin{array}{c}\text { No of negative } \\
\text { samples }(\%)\end{array}$ & $\begin{array}{l}\text { R/ship with factor @ } \\
\mathrm{p} \leq 0.05\end{array}$ \\
\hline Primary & 280 & $235(48.25)$ & $45(28.84)$ & 0.000 \\
Secondary & 207 & $152(31.21)$ & $55(35.26)$ & 0.000 \\
Tertiary & 156 & $100(20.53)$ & $56(35.89)$ & 0.000 \\
Total & $\mathbf{6 4 3}$ & $\mathbf{4 8 7}(\mathbf{7 5 . 7 3 )}$ & $\mathbf{1 5 6}(\mathbf{2 4 . 2 6 )}$ & \\
\hline
\end{tabular}

\section{Discussion}

In this study, it has been observed that Helicobacter pylori was more prominent in females than males. Out of the 487 (75.73\%) patients that had the organism, 296 (60.78\%) were females and 191(39.22\%) were males. Chi-Square test $(\mathrm{p}=0.000)$ further proved that the occurrence of Helicobacter pylori is related to gender and their relationship is significant. 
With regards to age, the highest isolation frequency was obtained from those patients above 50 years $(34.91 \%)$ and $41-50$ years $(23.82 \%)$. The least number of isolates were from those between $11-20$ years $(4.52 \%)$. Ananya et. al., 2012 opined that because prostaglandin levels in the gastric mucosa are decreased in elderly patients, ageing are associated with a diminished epithelial cell turnover rate and a reduced capacity to repair the gastric mucosa. Advanced age is therefore a major risk factor for complicated peptic ulcer disease.The ChiSquare test $(\mathrm{p}=0.000)$ therefore proved that there is a significant relationship between the occurrence of Helicobacter pylori and age.

Population density has been observed to be an important determinant of $\mathrm{H}$. pylori prevalence. It was observed that those patients living in a high density populated area or in an overcrowded environment had the highest number of isolates $252(51.75 \%)$, while the least isolates were from those living in a lesser or low density populated area $86(17.66 \%)$. The Chi-Square test $(\mathrm{p}=0.000)$ confirmed that the occurrence of H. pylori depended on population density and there relationship is significant.

It has been observed that the source of water supply used by the patients had an effect on the transmission of the infection. This probably, may be due to faecal contamination. It was observed that those patients that used stream water had the highest number of isolates, 147 (30.18\%). Also, those that used well water had $124(25.46 \%)$ isolates and the least isolates $60(12.32 \%)$ were from those who used tap water. The water from the well could have been contaminated through septic tanks or pit toilets located close to the well. The stream/river may also have been contaminated through the sewage from the septic tanks or pit toilets which is usually deposited into nearby stream or river thereby causing contamination. Therefore, faecal contaminated water is an important source of $\mathrm{H}$. pylori infection. Chi-Square test $(\mathrm{p}=0.002)$ also proved that there was a significant relationship between the occurrence of the organism and the source of water supply.

The type of toilet facility used by the patients had an effect on the occurrence of the organism. It was discovered that those that used water closet toilet had the greatest number of isolates, 191 (39.22\%), followed by those that used pit toilets, 159 (32.65\%).This was probably due to lack of basic hygiene after using the toilet. Some people do not wash their toilets regularly with soap and disinfectant, thereby increasing the rate of multiplication or spread of the organism. Therefore, low level of sanitation has been associated with increased prevalence of $\mathrm{H}$. pylori infection. Chi-Square test $(\mathrm{p}=0.000)$ confirmed that the relationship between the occurrence of the organism and the type of toilet facility used was significant.

It was observed that low level of education is associated with an increase in prevalence of H. pylori infection. Patients with primary education showed higher isolation rates, 235 (48.25\%) compared with 152 (31.21\%) of those with secondary education and $100(20.53 \%)$ with tertiary education. This may be due to lack of knowledge as regards to basic hygiene which has led to the increase in the prevalence rate. Chi-Square test $(\mathrm{p}=0.000)$ confirmed that there was a significant relationship between the occurrence of the organism and the level of education.

\section{Conclusion}

Helicobacter pylori is a major cause of peptic ulcer in human. The occurrence of this organism was strongly dependent on epidemiological factors such as over crowded or highly populated environment, which led to poor hygiene and dirty environment. Also, the use of untreated or faecal contaminated water, lack of basic hygiene with regards to the use of toilet and low level of education, all led to the increase in the prevalence rate of the infection. However, the occurrence of the organism can be controlled through proper disposal of human waste and it is also advised that wells should be dug away from pit toilets and septic tanks in order to avoid faecal contamination of the water source.

\section{References}

[1]. Cheesebrough, M. (2004). District Laboratory Practice in Tropical Countries. Part 2. Cambridge University Press.p. 125-267.

[2]. David, R.S., and George, S. (2009). Gastric Infection by Helicobacter pylori Gastroenterology, 11:455-461

[3]. Fozieh, J.M., Tahereh, N., and Mansour, A. (2014). Antibacterial Activity of Garlic

[4]. (Allium sativum) on Multidrug Resistance Helicobacter pylori Isolated from Gastric

[5]. Biopsies. International Journal of Enteric Pathogens, 2(2): 16749

[6]. Kohanteb, J., Bazargani, A., Saberi-Firoozi, M., and Mobasser, A. (2007). Antimicrobial Susceptibility testing of Helicobacter pylori to Selected Agents by Agar Dilution Method in Shiraz-Iran. Indian Journal of Medical Microbiology, 25 (4): $374-377$

[7]. Laura, O., Myra, W., Heriberto, F., Carola, O., Claddio, T., Victoria, C., Paula, R. and Luis, R. (2011). Isolation of Helicobacter pylori in Gastric Mucosa and Susceptibility to Five Antimicrobial Drugs in Southern Chile. Brazillian Journal of Microbiology, 42(2):442-447

[8]. Lyudmila, B. (2011). Epidemiology of Helicobacter pylori Infection. Horizon Scientific Press. www.horizonpress.com/helicobacter$\mathrm{p}$

[9]. Mohammed, M.K. Radwa, R.S. and Ramy, K.A. (2010).Helicobacter pylori; A Poor Man's gut Pathogen. Gut Pathogens, 2 (1): $1757-4749$

[10]. Raul, V. D., Eternity, D. L., Leah, J. B., Cirle, S. A., Venancio, I. G., Ma, L. D., and Richard, L. G. (2004). Laboratory Diagnosis and Susceptibility Profile of Helicobacter pylori infection in the Philippines. Annals of Clinical Microbiology and Antimicrobials, $3(25)$ 